\title{
PENGARUH KOMPOSISI BAKTERI PADA YOGURT DIFORTIFIKASI BUAH JAMBLANG (Syzygium cumini L.) TERHADAP KARAKTERISTIK ORGANOLEPTIK DAN TINGKAT KESUKAAN YOGURT
}

\author{
${ }^{1}$ Kiki Rizki Handayani \\ ${ }^{1}$ Sekolah Tinggi Ilmu Farmasi Pelita Mas Palu \\ kikirizkihandayani@gmail.com
}

\begin{abstract}
ABSTRAK
Yogurt merupakan hasil fermentasi susu dari bakteri asam laktat (BAL) seperti Lactobacillus bulgaricus dan Streptococcus thermophilus yang berperan pada pembentukan tekstur dan rasa yogurt. Oleh karena itu perlu diperhatikan perbandingan bakteri yang ditambahkan. Fortifikasi ekstrak buah jamblang (Syzygium cumini L.) bertujuan untuk meningkatkan nutrisi dan sebagai agen antioksidan. Penelitian ini bertujuan mengetahui perbandingan komposisi bakteri L. bulgaricus dan S. thermophilus yang tepat ditambahkan untuk mendapatkan yogurt terfortikasi buah jamblang dengan karakteristik organoleptik dan tingkat kesukaan yang paling baik. Ekstrak buah diperoleh dengan pemanasan $\left(54^{\circ} \mathrm{C}, 50\right.$ menit) (100 g ekstrak: $50 \mathrm{~mL}$ air). Komposisi bakteri L. bulgaricus dan S. thermophilus yang ditambahkan (1:1, 1:2, dan 2:1). Evaluasi yang dilakukan yaitu uji karakteristik organoleptik dan tingkat kesukaan pada yogurt. Analisis data menggunakan ANAVA (Analisis varian). Hasil menunjukkan yogurt terfortifikasi buah jamblang dengan bakteri L. bulgaricus dan $S$. thermophilus (1:1, 1:2, 2:1) memberikan pengaruh terhadap karakteristik organoleptik yogurt. Yogurt fortifikasi buah jamblang memiliki kualitas yang paling baik dibandingkan dengan yogurt tanpa forfikasi. Pada perlakuan tersebut menghasilkan karakteristik organoleptik warna (merah muda), aroma (sangat khas yogurt), rasa (agak asam), tekstur (agak halus) dan kekentalan (agak kental). Tingkat kesukaan tertinggi terdapat pada yogurt terfortifikasi buah jamblang dengan bakteri L. bulgaricus dan S. thermophilus 1:2.
\end{abstract}

Kata Kunci : Lactobacillus bulgaricus, Streptococcus thermophilus, Organoleptik

\section{PENDAHULUAN}

Upaya diversifikasi produk olahan susu semakin berkembang dikarenakan susu mudah mengalami kerusakan. Proses fermentasi digunakan untuk mengurangi kerusakan produk susu, salah satu produk susu fermentasi yang terkenal di masyarakat adalah yogurt (Kartikasari \& Nisa, 2014) Fermentasi susu menjadi yogurt dilakukan dengan bantuan bakteri asam laktat (BAL) seperti Lactobacillus bulgaricus dan Streptococcus thermophilus, yang berperan pada pembentukan tekstur dan rasa dari yogurt. Campuran kedua bakteri tersebut menghasilkan asam lebih banyak sehingga rasa yogurt menjadi lebih asam (Baglio, 2014) Oleh karena itu untuk menghasilkan yogurt dengan tekstur dan rasa yang baik perlu diperhatikan perbandingan antara kedua bakteri yang ditambahkan. 
Formulasi yogurt yang lebih menyehatkan dapat dilakukan fortifikasi untuk meningkatkan nutrisi pada yogurt, salah satunya dengan menambahkan buah-buahan sebagai agen antioksidan pada yogurt (Perina et al., 2015). Salah satu buah yang kaya akan antosianin adalah buah jamblang (Syzygium cumini L.). Kandungan antosianin buah jamblang segar yang matang sebesar 161 mg/100 g (Sari et al., 2009)

Penelitian ini bertujuan untuk mengetahui perbandingan komposisi bakteri L. bulgaricus dan $S$. thermophilus yang tepat ditambahkan untuk mendapatkan yogurt terfortikasi buah jamblang dengan karakteristik organoleptik dan tingkat kesukaan yang paling baik.

\section{METODE PENELITIAN}

\section{Alat dan Bahan Penelitian}

Alat dalam penelitian ini adalah alat gelas (Pyrex®), timbangan digital (Ohauss $\left.{ }^{\circledR}\right)$, inkubator (Memmert $^{\circledR}$ ), autoklaf $\quad\left(\right.$ Hirayama $\left.^{\circledR}\right)$, waterbath $\left(\mathrm{GFL}^{\circledR}\right)$, laminar air flow $\left(\right.$ Mascotte $\left.{ }^{\circledR}\right)$.

Bahan yang digunakan yaitu susu skim full krim $\left(\right.$ Dancow $\left.^{\circledR}\right)$, biakan murni Streptococcus thermophilus (ST), Lactobacillus bulgaricus (LB), dan madu. Sampel yang digunakan yaitu buah jamblang yang berasal dari kecamatan Kretek, Kabupaten Bantul, Kota Yogyakarta. Bagian buah yang digunakan adalah buah yang matang dengan warna ungu tua dengan panjang 2-3 cm.

\section{Prosedur Penelitian}

\section{Pembuatan Ekstrak Buah Jamblang}

Sampel buah sebanyak 100 gram ditambahkan $50 \mathrm{~mL}$ akuades, dihaluskan selama 3 menit, dan dipanaskan pada suhu $54^{\circ} \mathrm{C} \quad(50$ menit), kemudian disaring dan diperoleh ekstrak buah (Maran, dkk., 2014).

\section{Pembuatan Yogurt}

\section{Pembuatan Starter Bakteri}

Susu bubuk full cream $1,5 \mathrm{~g}$ dilarutkan dalam $10 \quad \mathrm{ml}$ air dipasteurisasi $\left(85^{\circ} \mathrm{C}, \quad 15\right.$ menit $)$ kemudian didinginkan sampai suhu $40^{\circ} \mathrm{C}$. Inokulasikan 1 ose kultur hasil pembiakan dari media MRS pada susu yang sudah dipasteurisasi, kemudian diinkubasi (24 jam, $\left.37^{\circ} \mathrm{C}\right)$. Masingmasing bakteri starter ditambahkan dalam $100 \mathrm{ml}$ susu skim yang telah dipasteurisasi $\left(85^{\circ} \mathrm{C}, 10\right.$ menit $)$ dan kembali diinkubasi (24 jam, $\left.37^{\circ} \mathrm{C}\right)$. Kultur starter siap digunakan.

\section{Pembuatan Yogurt Terfortifikasi}

Tahapan pembuatan yogurt meliputi pencampuran starter bakteri 
L. bulgaricus dan S. thermophilus (1:1, 1:2 dan 2:1), diaduk perlahan. Pasteurisasi susu skim full krim 100 $\mathrm{ml}\left(85^{\circ} \mathrm{C}, 10\right.$ menit $)$ didinginkan susu hingga $40^{\circ} \mathrm{C}$, kemudian ditambahkan campuran starter bakteri sebanyak 5\% $\mathrm{b} / \mathrm{v}$, dilanjutkan dengan inkubasi dalam inkubator $\left(37^{\circ} \mathrm{C}, 24\right.$ jam $)$. Yogurt terfortifikasi ditambahkan ekstrak buah jamblang dan madu. Kombinasi perlakuan dapat dilihat pada Tabel I.

\section{Tabel I Kombinasi Perlakuan}

\begin{tabular}{|c|c|c|c|c|c|c|}
\hline \multirow{2}{*}{ Bahan } & \multicolumn{6}{|c|}{ Komposisi (ml) } \\
\cline { 2 - 7 } & I & II & III & IV & V & VI \\
\hline Starter & & & & & & \\
\hline$L B$ & 2,5 & 2,5 & 5 & 2,5 & 2,5 & 5 \\
\hline$S T$ & 2,5 & 5 & 2,5 & 2,5 & 5 & 2,5 \\
\hline Ekstrak & 0 & 0 & 0 & 7,5 & 7,5 & 7,5 \\
\hline Madu & 8 & 8 & 8 & 8 & 8 & 8 \\
\hline Susu $13 \%$ & $\mathrm{ad}$ & $\mathrm{ad}$ & $\mathrm{ad}$ & $\mathrm{ad}$ & $\mathrm{ad}$ & $\mathrm{ad}$ \\
& 100 & 100 & 100 & 100 & 100 & 100 \\
\hline
\end{tabular}

\section{Uji Karakteristik Organoleptik dan} Tingkat Kesukaan

Pengujian menggunakan indra pengecap, pembau, penglihatan dan peraba. Uji yg termasuk dalam pengujian adalah kesukaan, rasa, aroma, warna, tekstur, dan kekentalan. Pengujian melibatkan 20 panelis. Uji karakterisasi organoleptik (deskriptif) dengan uji skoring bertujuan untuk mengetahui respon terhadap sifat-sifat produk diantaranya warna (putih ungu), aroma (khas yogurt - sangat khas buah Jamblang), rasa (sangat tidak asam - sangat asam), tekstur (sangat kasar - sangat halus), dan kekentalan (cair - sangat kental), skala uji deskriptif adalah 1-5. Skala uji tingkat kesukaan dibagi menjadi 7 tingkat: 1 (sangat tidak suka), 2 (tidak suka), 3 (agak tidak suka), 4 (netral), 5 (agak suka), 6 (suka), dan 7 (sangat suka) (Sunarlim, 2007).

\section{Analisa Data}

Analisis data menggunakan Analisis varian (ANAVA) satu jalur, apabila antara perlakuan menunjukkan perbedaan yang nyata, maka dilanjutkan dengan Uji Duncan.

\section{HASIL DAN PEMBAHASAN}

Yogurt Fortifikasi ekstrak buah jamblang bertujuan untuk menambah manfaat fungsional yogurt sebagai produk antioksidan karena mengandung senyawa antosianin (Sari et al., 2009) Parameter yang di uji untuk mengetahui karakteristik organoleptic dan tingkat kesukaan yogurt terdiri dari aroma, warna, tekstur, rasa, kekentalan (Setyaningsih, 2010)

\section{Pengaruh Perbandingan Bakteri dan Penambahan Ekstrak terhadap Warna Yogurt}

Penilaian Warna yang digunakan yaitu putih cerah, serta warna merah muda hingga ungu yang berasal dari ekstrak buah jamblang. Hasil penilaian 
uji kesukaan dan deskriptif pada warna yogurt dapat dilihat pada Tabel II.

Tabel II Pengaruh Perbandingan Bakteri dan Penambahan Ekstrak terhadap Warna Yogurt

\begin{tabular}{|c|c|c|}
\hline \multirow{2}{*}{ Warna } & \multicolumn{2}{|c|}{ Rata-Rata } \\
\cline { 2 - 3 } & Kesukaan & Deskriptif \\
\hline Plain LB 1:ST 1 & $4,75^{\mathrm{a}}$ & 1,00 \\
\hline Plain LB 1:ST 2 & $4,90^{\mathrm{a}}$ & 1,00 \\
\hline Plain LB 2:ST 1 & $5,00^{\text {ad }}$ & 1,00 \\
\hline Jamblang LB 1:ST 1 & $5,75^{\mathrm{c}}$ & 2,20 \\
\hline Jamblang LB 1:ST 2 & $5,70^{\mathrm{c}}$ & 2,10 \\
\hline Jamblang LB 2:ST 1 & $5,60^{\text {cd }}$ & 2,15 \\
\hline
\end{tabular}

\section{Keterangan:}

*Deskriptif: 1 = Putih, $2=$ Merah muda, $3=$ Merah, 4 = Ungu muda, 5 = Ungu

*Huruf kecil superscript yang berbeda pada kolom menunjukkan berbeda sangat nyata $(\mathrm{P}<0,01)$. Huruf kecil yang sama pada kolom menunjukkan tidak berbeda nyata $(\mathrm{P}>0,05)$

Penilaian tingkat kesukaan panelis terhadap warna yogurt yaitu agak suka hingga suka $(4,75-5,6)$, dan penilaian deskriptif menunjukkan warna putih pada yogurt plain dan merah muda pada yogurt difortifikasi ekstrak buah jamblang.

Yogurt terfortifikasi buah jamblang berbeda nyata dengan yogurt plain tanpa fortifikasi, sedangkan variasi kombinasi L. bacillus dan $S$. Thermopilus tidak berpengaruh terhadap penilaian warna. Warna merah muda pada yogurt difortifikasi buah jamblang lebih disukai. Hal ini disebabkan karena warna merupakan atribut organoleptik pertama yang dilihat oleh konsumen dan warna juga adalah salah satu yang berpengaruh terhadap tingkat kesukaan produk pangan (Apandi, 2016)

\section{Pengaruh Perbandingan Bakteri dan Penambahan Ekstrak terhadap Aroma Yogurt}

Aroma dapat mempengaruhi tingkat kesukaan pada suatu produk. Hasil penilaian uji tingkat kesukaan dan deskriptif terhadap aroma yogurt dapat dilihat pada Tabel III.

Tabel III Pengaruh Perbandingan Bakteri dan Penambahan Ekstrak terhadap Aroma Yogurt

\begin{tabular}{|c|c|c|}
\hline \multirow{2}{*}{ Aroma } & \multicolumn{2}{|c|}{ Rata-Rata } \\
\cline { 2 - 3 } & Kesukaan & Deskriptif \\
\hline Plain LB 1:ST 1 & $4,45^{\mathrm{a}}$ & 1,50 \\
\hline Plain LB 1:ST 2 & $4,65^{\mathrm{a}}$ & 1,55 \\
\hline Plain LB 2:ST 1 & $4,50^{\mathrm{a}}$ & 1,70 \\
\hline Jamblang LB 1:ST 1 & $4,20^{\mathrm{a}}$ & 2,15 \\
\hline Jamblang LB 1:ST 2 & $4,50^{\mathrm{a}}$ & 2,00 \\
\hline Jamblang LB 2:ST 1 & $4,30^{\mathrm{a}}$ & 2,10 \\
\hline
\end{tabular}

Keterangan:

*Deskriptif: 1 = Khas yogurt, 2 = Sangat khas yogurt, 3 = Agak khas buah jamblang, $4=$ Khas buah jamblang, 5 = Sangat khas buah jamblang. Huruf kecil yang sama pada kolom menunjukkan tidak berbeda nyata $(\mathrm{P}>0,05)$

Hasil uji kesukaan panelis pada aroma yaitu netral hingga agak suka (4,2-4,65), dan secara deskriptif menunjukkan yogurt beraroma khas yogurt hingga sangat khas yogurt (1,5$2,15)$.

Variasi kombinasi L. bacillus dan S. Thermopilus menunjukkan tidak berpengaruh nyata terhadap penilaian aroma oleh panelis. Aroma asam adalah aroma khas yogurt, hal ini 
disebabkan karena terbentuknya asam laktat selama proses fermentasi. Bakteri yang lebih berperan dalam pembentukan aroma asam pada yogurt yaitu bakteri L. bulgariccus (Hadi \& Fardiaz, 1990) Menurut Pintauro (1976) dalam Suryono (2005) aroma khas yogurt berasal dari senyawa yang terbentuk selama proses fermentasi seperti asam heksanoat, asam asetat, asam dekanoat, 2-undekanon, 2nonanon dan 2-indekanon.

\section{Pengaruh Perbandingan Bakteri dan Penambahan Ekstrak terhadap Rasa Yogurt}

Rasa asam adalah rasa khas yogurt, hal ini karena dalam proses fermentasi, bakteri asam laktat akan mengubah laktosa menjadi asam laktat yang menyebabkan penurunan $\mathrm{pH}$ dan peningkatan keasaman. Rasa merupakan faktor utama konsumen untuk memilih suatu produk pangan. Hasil penilaian uji kesukaan dan deskriptif terhadap rasa yogurt dapat dilihat pada Tabel IV.

Tabel IV Pengaruh Perbandingan Bakteri dan Penambahan Ekstrak terhadap Rasa Yogurt

\begin{tabular}{|c|c|c|}
\hline \multirow{2}{*}{ Rasa } & \multicolumn{2}{|c|}{ Rata-Rata } \\
\cline { 2 - 3 } & Kesukaan & Deskriptif \\
\hline Plain LB 1:ST 1 & $2,45^{\mathrm{a}}$ & 3,65 \\
\hline Plain LB 1:ST 2 & $2,80^{\mathrm{ab}}$ & 3,85 \\
\hline Plain LB 2:ST 1 & $3,10^{\mathrm{ab}}$ & 4,00 \\
\hline Jamblang LB 1:ST 1 & $4,00^{\mathrm{c}}$ & 3,60 \\
\hline Jamblang LB 1:ST 2 & $3,95^{\mathrm{c}}$ & 3,70 \\
\hline Jamblang LB 2:ST 1 & $3,45^{\mathrm{bc}}$ & 3,80 \\
\hline
\end{tabular}

Keterangan:

*Deskriptif: 1 = Sangat tidak asam, 2 = Tidak asam, 3 = Agak asam, $4=$ Asam, $5=$ Sangat asam. Huruf kecil superscript yang berbeda pada kolom menunjukkan berbeda sangat nyata $(\mathrm{P}<0,01)$. Huruf kecil yang sama pada kolom menunjukkan tidak berbeda nyata $(\mathrm{P}>0,05)$

\section{Penilaian tingkat kesukaan} panelis pada rasa menunjukkan nilai tidak suka hingga netral $(2,45-4)$, dan penilaian secara deskriptif menunjukkan yogurt memiliki rasa asam (3,6-4).

Yogurt terfortifikasi buah jamblang menunjukkan pengaruh nyata terhadap penilaian rasa. Yogurt terfortifikasi lebih disukai dibandingkan dengan yogurt plain. Hal ini disebabkan karena umumnya konsumen menyukai yogurt dengan penambahan citarasa pada tingkat tertentu sehingga yogurt tersebut memiliki citarasa dan keasaman yang disukai (Apandi, 2016)

Variasi perbandingan bakteri $L$. bulgaricus dan S. thermophilus tidak mempengaruhi rasa pada yogurt baik secara deskriptif maupun tingkat kesukaan. Rasa asam pada yogurt disebabkan karena senyawa yang terbentuk selama proses fermentasi seperti asam laktat, karbonil, asam asetat, aseton, asetaldehida, diasetil dan asetoin (Rusmiati et al., 2008) Pengaruh Perbandingan Bakteri dan 
Penambahan Ekstrak terhadap Tekstur Yogurt

$$
\text { Penilaian tekstur dalam }
$$
penelitian ini dilihat berdasarkan tingkat kehalusan yogurt. Tingkat kehalusan tekstur pada yogurt dapat diketahui setelah dikonsumsi, ditandai dengan kelembutan didalam mulut. Protein terlarut dalam susu merupakan fartor penting penentu tekstur yogurt (Winarno, F.G. \& Fernandez, 2007). Hasil penilaian uji kesukaan dan deskriptif terhadap tekstur yogurt dapat dilihat pada Tabel V.

\section{Tabel V Pengaruh Perbandingan Bakteri dan Penambahan Ekstrak terhadap Tekstur Yogurt}

\begin{tabular}{|c|c|c|}
\hline \multirow{2}{*}{ Tekstur } & \multicolumn{2}{|c|}{ Rata-Rata } \\
\cline { 2 - 3 } & Kesukaan & Deskriptif \\
\hline Plain LB 1:ST 1 & $4,70^{\mathrm{a}}$ & 3,60 \\
\hline Plain LB 1:ST 2 & $4,35^{\mathrm{a}}$ & 3,70 \\
\hline Plain LB 2:ST 1 & $4,30^{\mathrm{a}}$ & 3,70 \\
\hline Jamblang LB 1:ST 1 & $4,60^{\mathrm{a}}$ & 3,75 \\
\hline Jamblang LB 1:ST 2 & $4,75^{\mathrm{a}}$ & 3,90 \\
\hline Jamblang LB 2:ST 1 & $4,85^{\mathrm{a}}$ & 3,85 \\
\hline
\end{tabular}

Keterangan:

*Deskriptif: 1 = Sangat kasar, $2=$ Kasar, 3 = Agak halus, $4=$ Halus, $5=$ Sangat halus *Huruf kecil yang sama pada kolom menunjukkan tidak berbeda nyata $(\mathrm{P}>0,05)$

\section{Pengaruh Perbandingan Bakteri dan Penambahan Ekstrak terhadap Kekentalan Yogurt}

$$
\text { Penampilan makanan salah }
$$

satunya dipengarui oleh kekentalan atau viskositas suatu makanan (Jannah et al., 2014) Parameter kekentalan yang dinilai dalam penelitian ini yaitu cair hingga sangat kental. Protein terlarut dalam susu merupakan faktor penting yang mempengaruhi kekentalan suatu produk yogurt (Winarno, F.G. \& Fernandez, 2007). Hasil penilaian uji kesukaan dan deskriptif terhadap kekentalan yogurt dapat dilihat pada Tabel VI.

Tabel VI Pengaruh Perbandingan Bakteri dan Penambahan Ekstrak terhadap Kekentalan Yogurt

\begin{tabular}{|c|c|c|}
\hline \multirow{2}{*}{ Kekentalan } & \multicolumn{2}{|c|}{ Rata-Rata } \\
\cline { 2 - 3 } & Kesukaan & Deskriptif \\
\hline Plain LB 1:ST 1 & $4,50^{\mathrm{a}}$ & 4,50 \\
\hline Plain LB 1:ST 2 & $4,50^{\mathrm{a}}$ & 4,60 \\
\hline Plain LB 2:ST 1 & $4,60^{\mathrm{a}}$ & 4,60 \\
\hline Jamblang LB 1:ST 1 & $4,20^{\mathrm{a}}$ & 3,60 \\
\hline Jamblang LB 1:ST 2 & $4,25^{\mathrm{a}}$ & 3,70 \\
\hline Jamblang LB 2:ST 1 & $4,65^{\mathrm{a}}$ & 3,75 \\
\hline
\end{tabular}

\section{Keterangan:}

*Deskriptif: 1 = Agak cair, 2 = Cair, 3 = Agak kental, 4 = Kental, $5=$ Sangat kental

*Huruf kecil yang sama pada kolom menunjukkan tidak berbeda nyata $(\mathrm{P}>0,05)$

Hasil uji kesukaan yang dilakukan oleh panelis memberikan nilai 4,2-4,65 (netral hingga agak suka), sedangkan pada penilaian deskriptif menunjukkan yogurt mempunyai tekstur kental hingga sangat kental $(3,6-4,6)$. Kekentalan ini disebabkan karena selama proses inkubasi terjadi penurunan nilai $\mathrm{pH}$ yogurt melampaui titik isoelektrik protein casein pada 4,6, hal inilah yang menentukan kelarutan suatu protein casein selama waktu fermentasi sehingga menyebabkan penggumpalan protein susu akibat 
rendahnya pH (Handayani, 2007)

Penilaian Keseluruhan Tingkat Kesukaan pada Yogurt

Penilaian terakhir yang diamati dalam penelitian ini yaitu penilaian keseluruhan atau gabungan dari parameter tekstur, kekentalan, aroma, warna dan rasa (Muchtadi, 2010) Penilaian tingkat kesukaan yaitu dari sangat tidak disukai hingga sangat disukai. Hasil penilaian uji tingkat kesukaan terhadap penilaian keseluruhan pada yogurt dapat dilihat pada Tabel VII.

\section{Tabel VII Rata-rata Penilaian Uji Tingkat Kesukaan terhadap Penilaian Keseluruhan pada Yogurt.}

\begin{tabular}{|c|c|}
\hline $\begin{array}{c}\text { Perbandingan } \\
\text { Bakteri LB dan ST }\end{array}$ & $\begin{array}{c}\text { Nilai } \\
\text { Keseluruhan } \\
\text { (Kesukaan) }\end{array}$ \\
\hline Plain LB 1:ST 1 & $4,17^{\mathrm{a}}$ \\
\hline Plain LB 1:ST 2 & $4,24^{\mathrm{a}}$ \\
\hline Plain LB 2:ST 1 & $4,30^{\mathrm{a}}$ \\
\hline Jamblang LB 1:ST 1 & $4,55^{\mathrm{a}}$ \\
\hline Jamblang LB 1:ST 2 & $4,63^{\mathrm{a}}$ \\
\hline Jamblang LB 2:ST 1 & $4,57^{\mathrm{a}}$ \\
\hline
\end{tabular}

Keterangan:.

*Huruf kecil yang sama pada kolom menunjukkan tidak berbeda nyata $(\mathrm{P}>0,05)$

Secara keseluruhan tingkat kesukaan yogurt plain yang digunakan sebagai pembanding mempunyai skor 4,17 - 4,30 (Netral). Sedangkan yogurt dengan penambahan ekstrak buah jamblang disukai oleh panelis dengan skor $(4,55$ - 4,63). Hasil terbaik uji kesukaan terhadap yogurt yang dihasilkan dengan skor 4,63 adalah yogurt ekstrak buah jamblang dengan komposisi bakteri L. bulgaricus dan $S$. thermophilus 1:2.

\section{KESIMPULAN DAN SARAN}

\section{Kesimpulan}

1. Berdasarkan hasil penelitian yogurt terfortifikasi buah jamblang dengan perbandingan bakteri $L$. bulgaricus dan S. thermophilus $(1: 1, \quad 1: 2, \quad 2: 1)$. memberikan pengaruh terhadap karakteristik organoleptik yoghurt. Yogurt fortifikasi buah jamblang memiliki kualitas yang paling baik dibandingkan dengan yogurt tanpa forfikasi. Hal ini berdasarkan karateristik organoleptik (rasa, tekstur, warna dan aroma). Pada perlakuan tersebut menghasilkan karakteristik organoleptik warna (merah muda), aroma (sangat khas yogurt), rasa (agak asam), tekstur (agak halus) dan kekentalan (agak kental).

2. Tingkat kesukaan yoghurt berkisar antara 4,17-4,63. Dimana tingkat kesukaan tertinggi terdapat pada formula yogurt terfortifikasi buah jamblang dengan perbandingan komposisi bakteri L. bulgaricus dan S. thermophilus 1:2.

\section{Saran}


1. Bagi Peneliti selanjutnya, Perlu dilakukan uji kandungan lainnya dari yogurt terfortifikasi buah jamblang dengan perbandingan bakteri $S$. thermophilus dan $L$. bulgaricus.

2. Bagi Institusi, diharapkan dilakukan pengembangan terhadap produk yogurt terfortifikasi buah jamblang dengan perbandingan komposisi bakteri L. bulgaricus dan S. thermophiles sehingga dapat diterima oleh masyarakat.

3. Bagi Masyarakat, formula yogurt terfortifikasi buah jamblang dengan perbandingan komposisi bakteri $L$. bulgaricus dan $S$. thermophilus diharapkan dapat dijadikan sebagai produk yang bernilai ekonomi.

\section{UCAPAN TERIMA KASIH}

Terimakasih penulis sampaikan kepada Sekolah Tinggi Ilmu Farmasi Pelita Mas Palu yang telah membantu proses penelitian dalam bentuk dana hibah penelitian.

\section{DAFTAR PUSTAKA}

Apandi, I., Restuhadi, F., \& Yusmarini, Y. (2016). Analisis Pemetaan Kesukaan Konsumen (Consumer's Preference Mapping) terhadap Atribut Sensori Produk Soygurt Dikalangan Mahasiswa Fakultas
Pertanian Riau. Jom Faperta, 3(1).

Baglio, E. (2014). Chemistry and Technology of Yoghurt Fermentation (1st ed.). Springer international Publishing. https://doi.org/10.1007/978-3319-07377-4

Hadi, \& Fardiaz, S. (1990). Bakteri Asam Laktat dan Peranan dalam Pengawetan Makanan. Media Teknologi Pangan, 4(4), 73-74.

Handayani, E. (2007). Pembuatan Karamel dari Susu Sapi Kemasan dan Karakteristik Fisik serta pHnya. Institut Pertanian Bogor.

Jannah, A. M., Legowo, A. M., Pramono, Y. B., Al-baarri, A., \& Abduh, S. B. M. (2014). Total Bakteri Asam Laktat , pH , Keasaman , Citarasa dan Kesukaan Yogurt Drink dengan Penambahan Ekstrak Buah Belimbing. Jurnal Aplikasi Teknologi Pangan, 3(2), 7-11.

Kartikasari, D. I., \& Nisa, F. C. (2014). Pengaruh Penambahan Sari Buah Sirsak dan Lama Fermentasi terhadap Karakteristik Fisik dan Kimia Yoghurt. Jurnal Pangan Dan Agroindustri, 2(4), 239-248.

Muchtadi, T. R., Sugiono, \& Ayustaningwarno, S. (2010). Ilmu Pengetahuan Bahan Pangan. Alfabeta.

Perina, N. P., Granato, D., Hirota, C., Cruz, A. G., Bogsan, C. S. B., \& Oliveira, M. N. (2015). Effect of Vegetal-Oil Emulsion and Passion Fruit Peel-Powder on Sensory Acceptance of Functional Yogurt. Food Research International, 70, 134141.

https://doi.org/10.1016/j.foodres. 2015.01.014

Rusmiati, D., Sulistiyaningsih, R., Milanda, T., \& Kusuma, S. A. F. 
(2008). Metode Pembuatannya dengan Cara Sederhana dalam Rangka Peningkatan Derajat Kesehatan dan Ekonomi Masyarakat di Kelurahan Sukaluyu Kota Bandung.

Sari, P., Wijaya, C. H., Sajuthi, D., \& Supratman, U. (2009). Identifikasi Antosianin Buah Duwet (Syzygium cumini) Menggunakan Kromatografi Cair Kinerja Tinggi - Diode Array Detection. J. Teknolol. Dan Industri Pangan, 20(2), 102-108.

Setyaningsih, D., Apriyantono, A., \& Sari, M. P. (2010). Analisis Sensori untuk Industri Pangan dan Agro. Institut Pertanian Bogor Press.

Sunarlim, R., Setiyanto, H., \& Poeloengan, M. (2007). Pengaruh Kombinasi Starter Bakteri Lactobacillus bulgaricus, Streptococcus thermophilus dan Lactobacillus plantarum terhadap Sifat Mutu Susu Fermentasi. Seminar Nasional Teknologi Peternakan dan Veteriner.

Suryono, Sudono, A., Sudarwanto, M., \& Apriyantono, A. (2005). Studi Pengaruh Penggunaan Bifido Bakteria terhadap Flavor Yoghurt. Jurnal Teknologi Dan Industri Pangan, 16(1), 68-69.

Winarno, F. G., \& Fernandez, I. E. (2007). Susu dan Produk Fermentasinya (1st ed.). M-brio Press. 

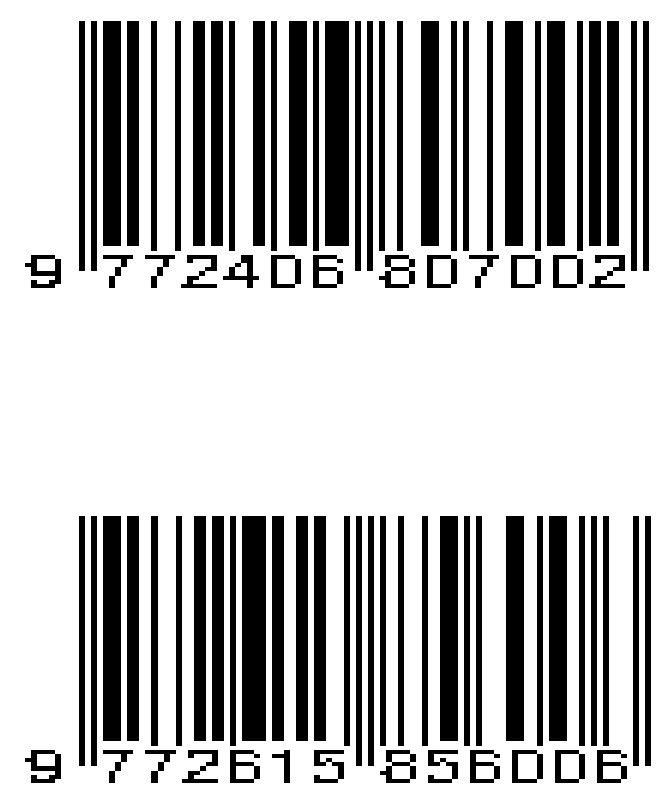